\title{
QUALITY OF 'TAHITI' ACID LIME FERTILIZED WITH NITROGEN AND POTASSIUM IN THE SEMIARID REGION OF MINAS GERAIS ${ }^{1}$
}

\author{
ARIANE CASTRICINI ${ }^{2}$, JOSÉ TADEU ALVES DA SILVA², \\ INÊZ PEREIRA DA SILVA ${ }^{3}$, MARIA GERALDA VILELA RODRIGUES ${ }^{2}$
}

\begin{abstract}
This study aimed to evaluate external characteristics and juice obtained from 'Tahiti' acid lime produced under nitrogen and potassium fertilization. This study had a completely randomized design with three replicates of four fruits of the two central plants, $4 \times 5$ factorial and four $\mathrm{N}$ doses $(0,25,50$ and $100 \mathrm{Kg} \mathrm{ha}^{-1}$ year $\left.^{-1}\right)$ and five $\mathrm{K}_{2} \mathrm{O}$ doses $\left(0,25,50,100\right.$ and $200 \mathrm{Kg} \mathrm{ha}^{-1}$ year $\left.{ }^{-1}\right)$, totaling 20 treatments. In the postharvest period, external characteristics (size, color and skin thickness, firmness and fresh mass) and juice (content, percentage, soluble solids, technological index, $\mathrm{pH}$, titratable acidity, ratio and ascorbic acid) of fruits were evaluated. Size, skin color, soluble solids content and $\mathrm{pH}$ of 'Tahiti' acid lime juice were not affected by $\mathrm{N}$ and $\mathrm{K}_{2} \mathrm{O}$ fertilization. Skin thickness, juice percentage and technological index increased with the $\mathrm{N}$ and $\mathrm{K}_{2} \mathrm{O}$ doses applied to the soil. Juice content and fruit firmness decreased with application of $\mathrm{K}_{2} \mathrm{O}$ doses. Titratable acidity and ascorbic acid content increased with $\mathrm{K}_{2} \mathrm{O}$ doses. The different nitrogen and potassium doses influenced more the juice quality than the external characteristics of 'Tahiti' acid lime in the postharvest period.
\end{abstract}

Index Terms: Citrus latifolia Tanaka, postharvest, size, color, juice.

\section{QUALIDADE DE LIMA ÁCIDA 'TAHITI' ADUBADA COM NITROGÊNIO E POTÁSSIO NO SEMIÁRIDO DE MINAS GERAIS}

RESUMO- Objetivou-se avaliar as características externas e as do suco de lima-ácida 'Tahiti’, produzida sob adubação nitrogenada e potássica. Utilizou-se o delineamento inteiramente casualizado, com três repetições de quatro frutos das duas plantas centrais, em esquema fatorial $4 \times 5$, sendo quatro doses de $\mathrm{N}(0 ; 25 ; 50 \mathrm{e}$ $100 \mathrm{Kg}$. ha ${ }^{-1}$. ano $\left.{ }^{-1}\right)$ e cinco doses de $\mathrm{K} 2 \mathrm{O}\left(0 ; 25 ; 50 ; 100\right.$ e $200 \mathrm{~kg}$. ha ${ }^{-1}$. ano-1), totalizando 20 tratamentos. Em pós-colheita, avaliaram-se as características externas (tamanho, cor e espessura da casca, firmeza e massa fresca) e as do suco (volume, percentagem, sólidos solúveis, índice tecnológico, $\mathrm{pH}$, acidez titulável, ratio e ácido ascórbico dos frutos). O tamanho, a cor da casca, o teor de sólidos solúveis e o pH do suco de lima ácida 'Tahiti' não foram influenciados pelas adubações com $\mathrm{N} \mathrm{e} \mathrm{K}_{2} \mathrm{O}$. A espessura da casca, a porcentagem de suco e o índice tecnológico aumentaram com as doses de $\mathrm{Ne} \mathrm{K}_{2} \mathrm{O}$ aplicadas no solo. O volume de suco e a firmeza do fruto reduziram com as aplicações das doses de $\mathrm{K}_{2} \mathrm{O}$. A acidez titulável e o teor de ácido ascórbico aumentaram com as doses de $\mathrm{K}_{2} \mathrm{O}$. As diferentes doses de adubação nitrogenada e potássica influenciaram mais na qualidade do suco que nas características externas de lima-ácida 'Tahiti', em pós-colheita.

Termos para Indexação: Citrus latifolia Tanaka, pós-colheita, tamanho, cor, suco.

\footnotetext{
${ }_{1}^{1}$ (Paper 250-15). Received on October 28, 2015. Accepted March 09, 2016.

${ }^{2}$ Agronomist, DSc. Fapemig Fellowship. Epamig Norte de Minas, Epamig, Rodovia MGT 122, Km 155, Cep.: 39525-000, Nova Porteirinha, Minas Gerais - Brasil. ariane@epamig.br; josetadeu@epamig.br; magevr@epamig.br.

${ }^{3}$ Post doctorate fellowship - Fapemig/Epamig, Rodovia MGT 122, Km 155, Caixa Postal 12,CEP 39525-000 Nova Porteirinha, MG. Email: inezps@yahoo.com.br
} 


\section{INTRODUCTION}

The northern region of Minas Gerais accounts for $52.6 \%$ of the state's 'Tahiti' acid lime (Citrus latifolia Tanaka) production. In the Irrigated Perimeter of semiarid Jaíba, 'Tahiti' acid lime is the second most important agricultural activity, with total planted area of 1500 ha, with production of 42,000 tons (IBGE, 2012). The region has characteristics for the development of citrus, such as low incidence of pests and diseases, rainfall around $800 \mathrm{~mm} /$ year and climatic conditions that, together with irrigation, allow the flowering of 'Tahiti' acid lime tree throughout the year (AZEVEDO et al., 2010).

According to Silva (2015) in Brazil, there are few scientific publications on 'Tahiti' lemon fertilization, mainly with $\mathrm{N}$ and $\mathrm{K}_{2} \mathrm{O}$. Fertilization recommendations currently made for this crop are mostly based on data obtained from research on orange crop, which is the most studied citrus plant, mainly on fertilization and nutrition.

The quality of fruits demands special care in crop fertilization. According to Aular and Natale (2013), there is no single behavior for the effects of nutrients on quality. The soil and climatic conditions, the cultivar and the nutrient dose are determinant. Maximum production and the best quality of fruits also depend on the balance among nutrients. Thus, the proportion of elements in the plant tissue plays a more important role than the absolute content of each nutrient.

According to Quaggio et al. (2006) and Mattos Júnior et al. (2014), both the lack and excess of $\mathrm{N}$ directly interfere in the size and quality of fruits because high $\mathrm{N}$ doses tend to increase the number of fruits per plant to the detriment of their size, which can be a disadvantage for the fresh fruit market.

High $\mathrm{K}_{2} \mathrm{O}$ doses increase the fruit size and skin thickness, which are desired for the fresh fruit market. However, plants with high $\mathrm{K}$ supply tend to produce fruits with higher acidity and lower soluble solids content, depreciating them for the juice processing industry (ALVA et al., 2006; QUAGGIO et al. 2006).

Citrus juice processing industries consider physical and chemical parameters such as acidity, $\mathrm{pH}$, ratio, soluble solids, ascorbic acid, essential oil, color and viscosity not only to control the quality of the product, but also to meet the requirements established by the consumer market (PACHECO et al., 2014). However, in the recent literature, no studies correlating fertilization with most of the physical and chemical parameters studied in postharvest are found.
For classification of 'Tahiti' acid lime according to Ceagesp standards, skin color, size and defects (severe, mild and spots) are taken into account. The quality standards used for export are: rough skin, bright olive green color and diameter of the equatorial region between 47 and $65 \mathrm{~mm}$. However, according to Nascimento and Santos (2013), the lack of fruit quality, especially in relation to the rapid loss of skin color, which tends to yellowing after harvesting, limits the opening of new international markets for Brazilian producers of this cultivar.

The study of the post-harvest quality of 'Tahiti' acid lime as a function of fertilization, together with the phytotechnical responses, could guide the management of soil fertility and mineral nutrition of plants in the irrigated perimeter of Jaíba. Therefore, the aim of this study was to evaluate the external characteristics and juice of 'Tahiti' acid lime produced under nitrogen and potassium fertilization.

\section{MATERIAL AND METHODS}

The experiment was conducted in four harvest seasons, in 2009, 2010, 2011 and 2012, in the municipality of Jaíba, located in the semiarid region of northern Minas Gerais, Brazil. The geographic coordinates are: $15^{\circ} 48$ ' 09 ' $\mathrm{S}, 43^{\circ} 18^{\prime}$ ” $32^{\prime} \mathrm{W}, 533 \mathrm{~m}$ a.s.l. and average annual rainfall of $800 \mathrm{~mm}$, average temperature of $25{ }^{\circ} \mathrm{C}$ and $56 \%$ relative humidity. The soil of the experimental area is classified as Typic Quartzipisamment and had the following characteristics in the 0 to $0.20 \mathrm{~m}$ layer: $\mathrm{pH}\left(\right.$ in $\left._{2} \mathrm{H}_{2} \mathrm{O}\right)$ = 6.6; $\mathrm{Al}$ exchangeable $\left(\mathrm{cmolc} \mathrm{dm}^{-3}\right)=0.0 ; \mathrm{H}+\mathrm{Al}$ $\left.\left.(\mathrm{cmolc} \mathrm{dm})^{-3}\right)=1.1 ; \mathrm{Ca}=(\operatorname{cmolc~dm})^{-3}\right)=1.6$ and $\mathrm{Mg}\left(\mathrm{cmolc} \mathrm{dm}^{-3}\right)=0.6$; P-Mehlich $1\left(\mathrm{mg} \mathrm{dm}^{-3}\right)=$ 8.7; K-Mehlich $1\left(\mathrm{mg} \mathrm{dm}^{-3}\right)=29.5$; Organic matter $=6.0 \mathrm{~g} \mathrm{~kg}^{-1}$; Sand $=85 \mathrm{~g} \mathrm{~kg}^{-1}$; Clay $=10 \mathrm{~g} \mathrm{~kg}^{-1}$ and Silt $=5 \mathrm{~g} \mathrm{~kg}^{-1}$.

The work was carried out in a twelvemonth-old 'Tahiti' (Citrus latifolia Tanaka) orchard grafted on 'Cravo' lemon tree (Citrus limonia L. Osbeck). The planting of seedlings was carried out in pits with dimensions of $0.40 \times 0.40 \times 0.40 \mathrm{~m}$ and spacing of $8 \mathrm{~m}$ between rows and $5 \mathrm{~m}$ between plants. Fertilization was carried out with applications of $120 \mathrm{~g}$ of $\mathrm{P}_{2} \mathrm{O}_{5}$ and 15 liters of bovine manure in the pit. Phosphate fertilization was applied once a year according to soil analysis, as recommended by the Fertilizer and Liming Group of São Paulo for citrus (1994). Simple superphosphate was used as source of phosphorus. Micronutrients were applied four months after planting using $50 \mathrm{~g}$ of FTE BR-12 
plant $^{-1}$ (S: $3.9 \%$, B: $1.8 \%$, Mn: $2.0 \%$ and Zn: $9.0 \%$ ) and repeated once a year. $\mathrm{N}$ and $\mathrm{K}_{2} \mathrm{O}$ applications started with the applications of experiment treatments twelve months after the planting of seedlings.

Treatments were distributed in the field in a randomized block design, with four replicates, in a $4 \times 5$ factorial scheme, corresponding to four $\mathrm{N}$ doses $\left(0,25,50\right.$ and $100 \mathrm{~kg} \mathrm{ha}^{-1}$ year $\left.^{-1}\right)$ and five $\mathrm{K}_{2} \mathrm{O}$ doses $\left(0,25,50,100\right.$ and $200 \mathrm{~kg} \mathrm{ha}^{-1}$ year $\left.^{-1}\right)$, totaling 20 treatments and 80 experimental units. These doses were divided and applied monthly on the soil surface, in the projection of the plant canopy. $\mathrm{N}$ and $\mathrm{K}_{2} \mathrm{O}$ sources were urea and potassium chloride, respectively.

Each plot of the experiment consisted of four plants and the useful portion of the two central plants. The experiment was irrigated using the microsprinkler system with water depth management by means of evaporation measurements of the class A tank.

In the fourth year of production, 12 fruits per useful plant were harvested, totaling 24 fruits per useful portion of each treatment. The point of harvest was defined by the absence of roughness and by the dark green skin coloration, which is equivalent to C2 coloration, according to Ceagesp classification. After harvest, fruits were transported in plastic boxes to the Post-Harvest Laboratory of the Gorutuba Experimental Field, which belongs to Epamig, for evaluations. For post-harvest analysis, a completely randomized design with three replicates was used, each composed of four fruits.

The post-harvest quality of fruits was evaluated through chemical and physical characteristics and, for organization purposes, characteristics were divided into external and juice, as described below:

1) External characteristics: (a) fruit length obtained with the aid of a digital caliper, measured from one end to the other, in $\mathrm{mm}$; b) fruit diameter also obtained with digital caliper, measured in the median region, expressed in $\mathrm{mm}$; c) skin thickness measured with pachymeter, considering the thickness occupied by flavedo and albedo after cutting fruits in the equatorial region, expressed in $\mathrm{mm}$; d) fruit firmness measured in the central region, with digital penetrometer, expressed in $\mathrm{N}$; e) fresh fruit mass obtained by weighing in semi-analytical scale expressed in g; c) skin color determined by Minolta Colorimeter, model Chroma meter CR 400, LCH system, which expresses color through luminosity ( $\mathrm{L}$ $*)$, chromaticity or color purity $(\mathrm{C} *)$ and hue angle ( $\left.{ }^{\circ} \mathrm{Hue}\right)$, which varies between $0^{\circ}$ and $360^{\circ}$, where $0^{\circ}$ corresponds to red color, $90^{\circ}$ to yellow color, $180^{\circ}$ or $-90^{\circ}$ to green color, $270^{\circ}$ or $-180^{\circ}$ to blue color, and goes from red to black in $360^{\circ}$.

2) Juice characteristics: a) volume, after extraction in juice extractor, expressed in $\mathrm{ml}$; b) percentage - fruits of each repetition were weighed and then the juice extracted with a conical extractor was weighed. The juice percentage was calculated using the formula: $\%$ juice $=[$ juice mass $(\mathrm{g}) /$ fruit mass (g)] x 100; c) soluble solids content determined in digital refractometer, with results expressed in ${ }^{\circ}$ Brix; d) technological index (T.I.) calculated by the formula: T.I. $=($ soluble solids $\mathrm{x} \%$ juice $) / 100 ; \mathrm{e})$ $\mathrm{pH}$ determination in digital $\mathrm{pH}$; $\mathrm{f}$ ) titratable acidity determined according to the AOAC (1995): in $10 \mathrm{~mL}$ of juice, titration was performed with $0.5 \mathrm{~N} \mathrm{NaOH}$ to $\mathrm{pH} 8.0$, and the results were expressed as $\%$ (mg citric acid / $100 \mathrm{~mL}$ of ); g) ratio: ratio between soluble solids content and titratable acidity and $\mathrm{h}$ ) ascorbic acid content according to CARVALHO et al. (1990): $10 \mathrm{~mL}$ of juice were placed in Erlenmeyer flask containing $50 \mathrm{~mL}$ of $1 \%$ oxalic acid solution. Titration was performed with DCFI (2,6-dichlorophenol indophenol) until persistent pink coloration was achieved for 15 seconds. The results were expressed as mg ascorbic acid per 100 $\mathrm{mL}$ of juice.

Data that compose each repetition were obtained from the average of readings in four fruits, both for the external and juice characteristics.

Statistical analysis was performed using the Saeg 9.1 software (2007). Before analysis of variance, normality test was performed (Lilliefors). ANOVA was performed considering $4 \times 5$ factorial, being the first factor corresponding to the four doses of $\mathrm{N}$ and the second factor, to the five $\mathrm{K}_{2} \mathrm{O}$ doses. The significant effects of factors were studied by linear or quadratic regression analysis.

\section{RESULTS AND DISCUSSION}

All external and juice data evaluated showed normal distribution, with calculated values being lower than the table values $(0,114)$, for $p=0.05$. There was no significant interaction between $\mathrm{N}$ and $\mathrm{K}_{2} \mathrm{O}$ doses for the external and juice variables for 'Tahiti' acid lime.

Length, diameter, fresh mass, soluble solids content, fruit $\mathrm{pH}$, and $\mathrm{L} *$ and $\mathrm{C} *$ parameters of skin color were not influenced by the individual effects of $\mathrm{N}$ and $\mathrm{K}_{2} \mathrm{O}$ fertilizations. The mean values, regardless of doses of fertilizers, were: fruits with $56.32 \mathrm{~mm}$ and $52.56 \mathrm{~mm}$ in length and diameter, respectively, 
fresh mass of $86.15 \mathrm{~g}$, skin with luminosity ( $\mathrm{L} *$ ) of 48.40 and chroma $\left(\mathrm{C}^{*}\right)$ of 39.02 , soluble solids of 9, $10^{\circ}$ Brix and $\mathrm{pH} 2.23$.

Fruits presented size (length and diameter) that meets the fresh fruit market demand, because according to Luchetti et al. (2003), fruits with size of approximate 55 to $70 \mathrm{~mm}$ in length and 47 to $65 \mathrm{~mm}$ in diameter are preferred by the fresh fruit market.

The hue angle was influenced by the effect of $\mathrm{N}$ doses, while firmness and juice volume were affected by $\mathrm{K}_{2} \mathrm{O}$ doses. There was a reduction in the hue angle with increased nitrogen fertilization until approximately $300 \mathrm{~g} \mathrm{plant}^{-1}$ year $^{-1}$. From this dose, a slight increase in the angle is observed, that is, the green skin color became more intense (Figure 1A). Despite the reduction, the values are within the range of green tonality, which is desirable for the commercialization of 'Tahiti' acid lime. $\mathrm{N}$ is an essential element, structural component of proteins, chlorophyll and nucleic acids and influences fruit quality, because its deficiency affects fruit production and size, which present thin skin, pale green color and early maturation (MAGALHÃES, 2006).

The maintenance of the dark green color of 'Tahiti' lime skin is desirable during its post-harvest life, while total or partial yellow coloration prevents its acceptance by the consumer (TAVARES et al., 2004). According to Bassan et al. (2016), fruits under marketing conditions are turgid, with green bark, without rotting and physiological disturbances. Mattos Junior et al. (2010) verified that the $\mathrm{N}$ content in the leaf of 'Tahiti' acid lime was positively correlated with the green color of the fruit skin, that is, the higher leaf $\mathrm{N}$ content of fruits, the more intense their green color.

Increasing $\mathrm{K}_{2} \mathrm{O}$ doses reduced fruit firmness and juice volume (Figure 1B and C, respectively). The firmness of 'Fuji' apple pulp also reduced with increasing $\mathrm{K}_{2} \mathrm{O}$ doses and their excess may favor the appearance of physiological disturbances and limit the longevity of these fruits, as they decrease pulp firmness (HUNSCHE et al. 2013). According to Souza et al. (2013), firmness of apples decreased in response to high $\mathrm{K}_{2} \mathrm{O}$ doses in a Cambisol, regardless of $\mathrm{N}$ doses.

According to Pacheco et al. (2014), fruits with low firmness present less resistance to transportation, storage and handling and are therefore rejected by consumers. Although K was considered an "element of quality", under the conditions of the present work, the use of increasing $\mathrm{K}_{2} \mathrm{O}$ doses reduced fruit firmness.

Quadratic regression was best adjusted for the tendency of skin thickness of 'Tahiti' acid lime as a function of the $\mathrm{N}$ (Figure 2A) and $\mathrm{K}_{2} \mathrm{O}$ doses (Figure 2B). $\mathrm{N}$ and $\mathrm{K}_{2} \mathrm{O}$ doses that provided maximum skin thickness were 59 and $140 \mathrm{~kg} \mathrm{ha}^{-1}$ year $^{-1}$ of $\mathrm{N}$ and $\mathrm{K}_{2} \mathrm{O}$, respectively. According to Alva et al. (2006), high $\mathrm{K}_{2} \mathrm{O}$ doses cause increased fruit size and skin thickness, which are desirable qualities for the fresh fruit market; however, plants with high $\mathrm{K}$ supply tend to produce fruits with higher acidity and lower content of solids, which depreciates fruits for the juice industry.

$\mathrm{K}$ is the nutrient responsible for the maintenance of turgor and extensibility of cells, affecting fruit size. Studies have shown that K increases fruit size and skin thickness, which are characteristics favorable to the fresh fruit market. However, larger fruits with thicker skin may have lower juice yield and lower soluble solids contents, which are undesirable for the production of concentrated juice (MATTOS Jr.; QUAGGIO; CANTARELLA, 2005).

Juice percentage, expressed as a function of fruit size, linearly increased with $\mathrm{N}$ (from $66 \%$ to $69 \%$ ) (Figure $3 \mathrm{~A}$ ) and $\mathrm{K}_{2} \mathrm{O}$ doses (from $53 \%$ to $95 \%$ ) (Figure 3B). According to Pacheco et al. (2014), juice yield around $54 \%$ is desired by both fresh fruit market and the juice processing industry. In the present work, both $\mathrm{N}$ and $\mathrm{K}_{2} \mathrm{O}$ doses provided juice yield over $50 \%$.

In order to obtain the juice percentage, fruit mass was considered in the denominator of the equation; however, there was no significant difference for fresh fruit mass as a function of fertilization. It is suggested, therefore, that the $\mathrm{N}$ and $\mathrm{K}_{2} \mathrm{O}$ doses influenced not only the juice mass gain, but also the other factors involved in the fruit filling process, such as number of vesicles containing the juice or "bagasse". Mendonça et al. (2006) evaluated the yield of 'Tahiti' acid lime fractions, among which, the juice percentage was $50.1 \%$ in relation to the other fractions studied. In the present work, the increase in the juice percentage with maintenance of fruit mass suggests variations in the other fruit fractions as a function of fertilization.

Linear regression was the best fit between $\mathrm{N}$ (Figure 3C) and $\mathrm{K}_{2} \mathrm{O}$ fertilization (Figure 3D) and technological indexes. The calculation of this quality indicator considered soluble solids content that was not influenced by $\mathrm{N}$ and $\mathrm{K}_{2} \mathrm{O}$ fertilizations, and juice $\%$ that increased proportionally to the increase in $\mathrm{N}$ and $\mathrm{K}_{2} \mathrm{O}$ doses. The technological index is not the result of a measurement, but rather a calculation, which parameters are the soluble solids content and the juice yield; being influenced by all factors affecting the trend of these parameters, such as climatic conditions, irrigation and fertilization 
(VOLPE et al., 2002).

In the industry, fruits with the highest industrial yield indexes are the most desirable. Quality indexes relating solid soluble contents and industrial yields are already used for the differentiated payment of citrus and passion fruits, and this trend has been adopted by agroindustries. Nitrogen fertilization did not influence the titratable acidity of the acid file, which presented an average value of $5.3 \%$ in the different $\mathrm{N}$ doses. The regression that best fit between $\mathrm{K}_{2} \mathrm{O}$ doses and titratable acidity was the quadratic one (Figure 4A), where maximum acidity (5.7\%) was obtained with $\mathrm{K}_{2} \mathrm{O}$ application of $124 \mathrm{~kg} \mathrm{ha}^{-1}$ year $^{-1}$. The increase in titratable acidity with $\mathrm{K}_{2} \mathrm{O}$ doses can be attributed to the higher concentration of organic acids in the juice due to the reduction in the juice volume with increased potassium fertilization (Figure 1C). Unlike titratable acidity, ratio decreased with $\mathrm{K}_{2} \mathrm{O}$ doses (Figure 4B). This variable is calculated by the solid soluble / titratable acidity ratio, since there was no effect of fertilizations on soluble solids content, and acidity increased proportionally to the potassium fertilization, the ratio reduced with increasing $\mathrm{K}_{2} \mathrm{O}$ doses.
Almeida and Baumgartner (2002) found that higher $\mathrm{K}_{2} \mathrm{O}$ dose $\left(150 \mathrm{~kg} \mathrm{ha}^{-1}\right)$, compared to the others, caused an increase in the acidity of 'Valencia' orange juice only within the lowest $\mathrm{N}$ dose $(94 \mathrm{~kg}$ ha ${ }^{-1}$ of $\left.\mathrm{N}\right)$, while intermediate $\mathrm{K}_{2} \mathrm{O}$ dose $\left(75 \mathrm{~kg} \mathrm{ha}^{-1}\right)$ caused a decrease in the soluble solids content, only within the highest $\mathrm{N}$ dose. The effect of $\mathrm{K}_{2} \mathrm{O}$ doses on juice acidification is consistent with literature (ALVA et al., 2006; QUAGGIO et al., 2006).

Quadratic regression was the best fit between ascorbic acid content and $\mathrm{K}_{2} \mathrm{O}$ doses (Figure 4C) and there was no significant effect of $\mathrm{N}$ on this variable. The maximum ascorbic acid content (62.5 $\mathrm{mg}$ ascorbic acid / $100 \mathrm{ml}$ juice) was obtained with $\mathrm{K}_{2} \mathrm{O}$ dose of $100 \mathrm{~kg} \mathrm{ha}^{-1}$ year ${ }^{-1}$. Bernardi et al. (2007) also verified quadratic response of ascorbic acid values of tomatoes in relation to $\mathrm{K}_{2} \mathrm{O}$ doses applied in fertilization; and according to the authors, $\mathrm{K}$ supply has a positive effect on the ascorbic acid concentration due to the increased availability of the nutrient.
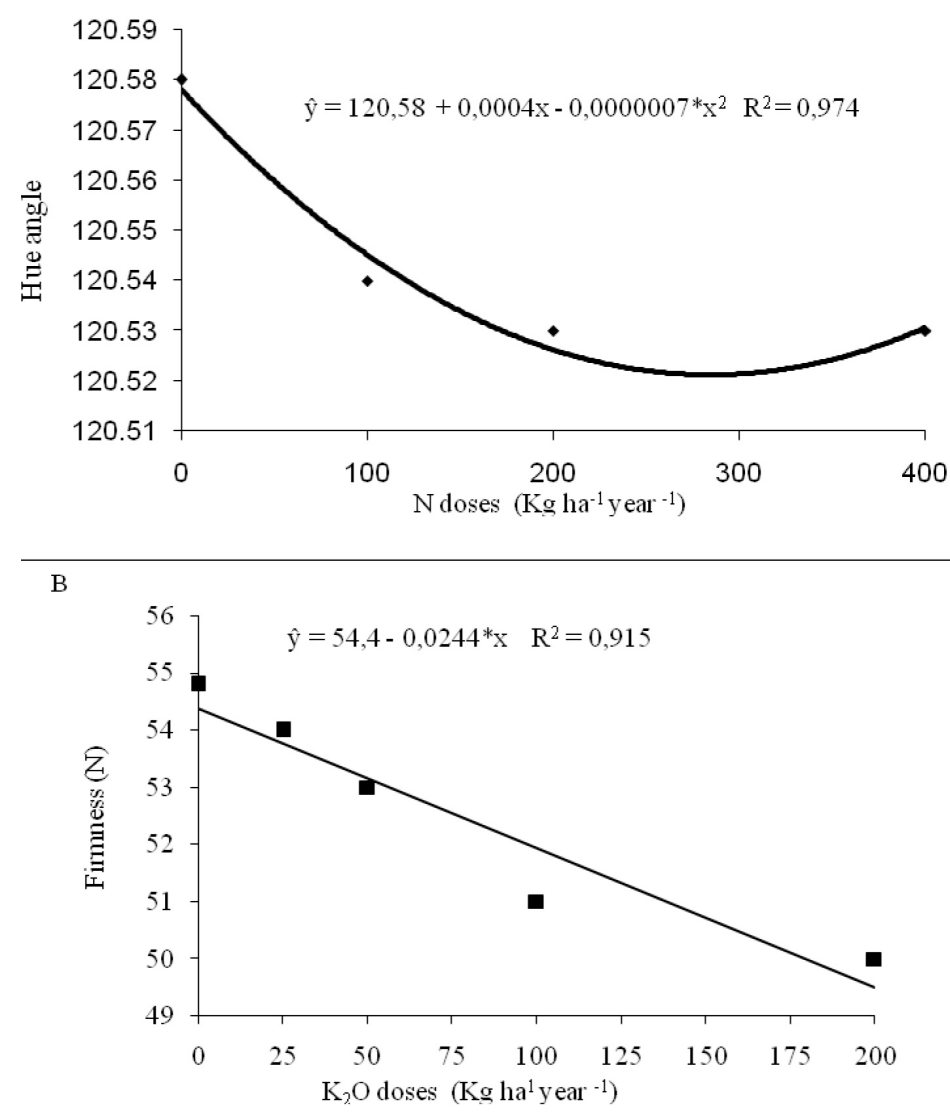

continue.. 


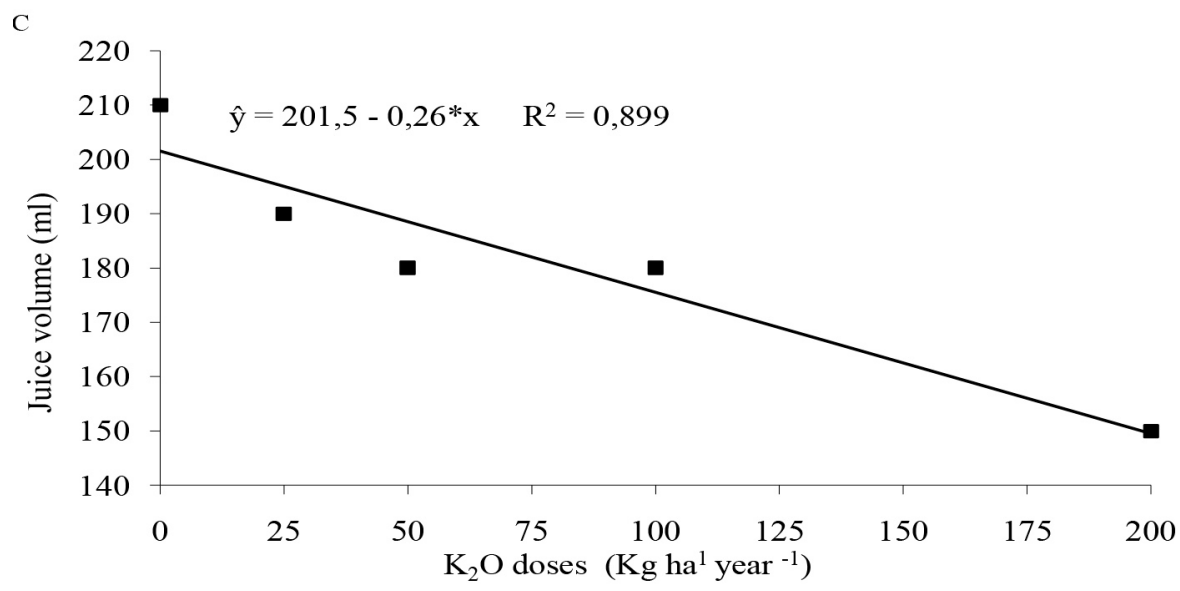

FIGURE 1- Hue angle (A) of 'Tahiti' acid lime skin as a function of nitrogen rates applied to the soil and Firmness (B) and juice volume (C) of 'Tahiti' acid lime as a function of applied potassium doses. * = Significant at $5 \%$ probability.

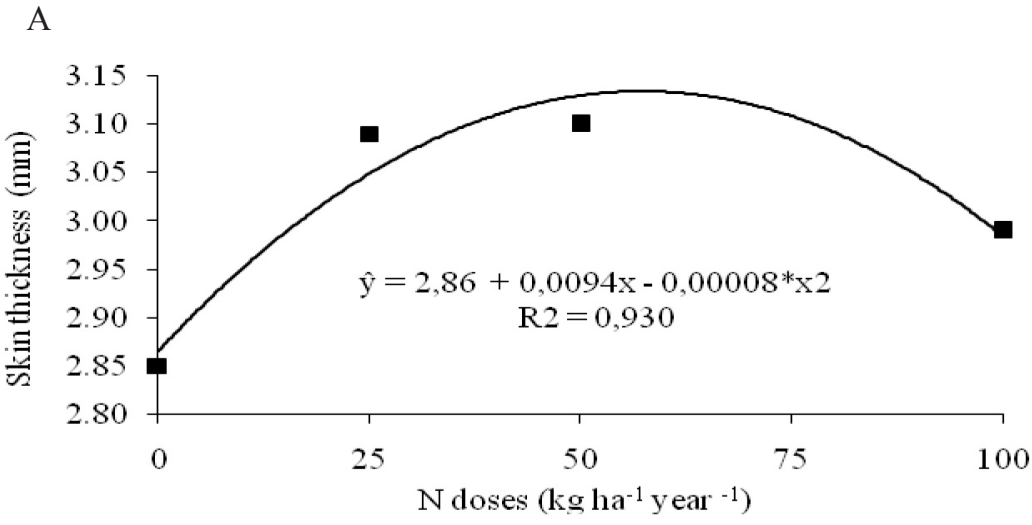

$\mathrm{B}$

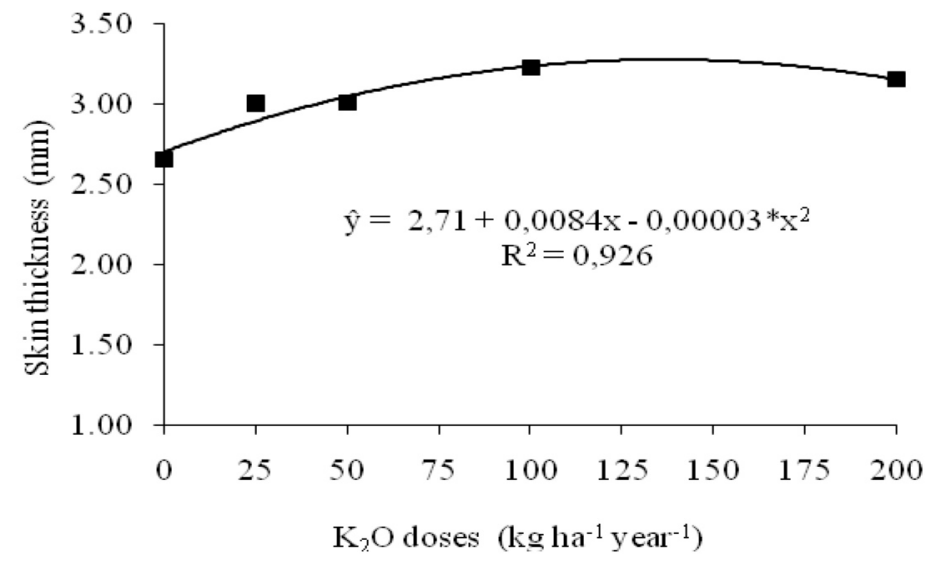

FIGURE 2 - Skin thickness of 'Tahiti' acid lime as a function of nitrogen (A) and potassium (B) doses applied to the soil.

* = Significant at $5 \%$ probability. 
A

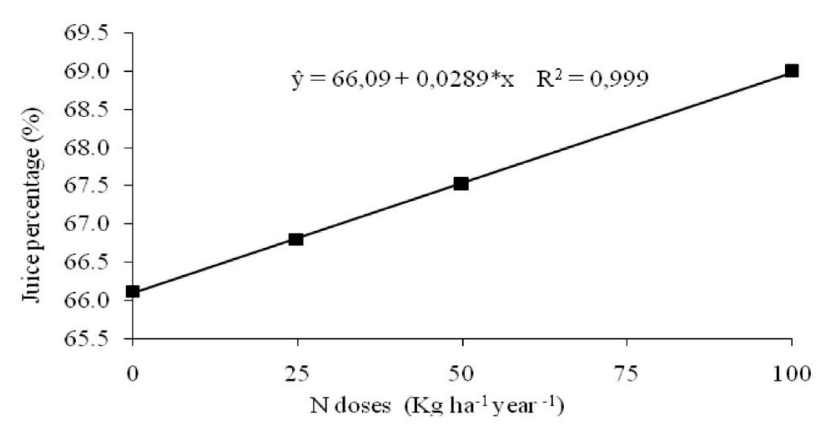

$\mathrm{B}$

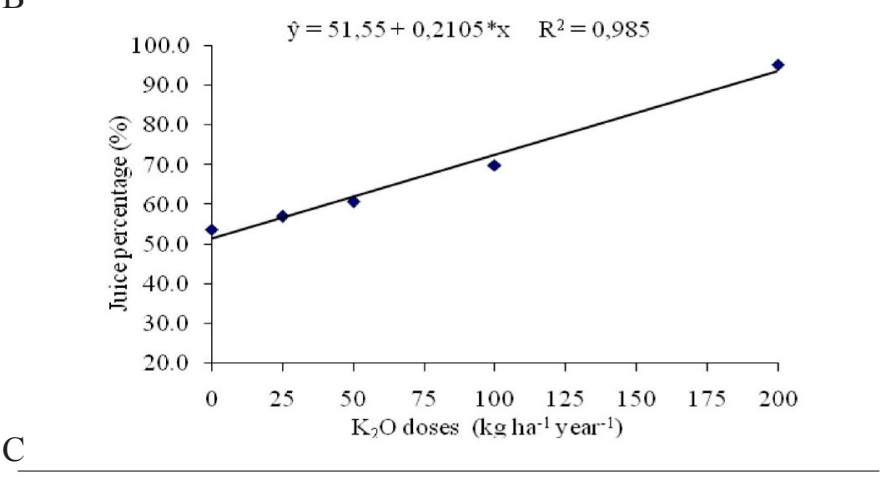

$\mathrm{C}$
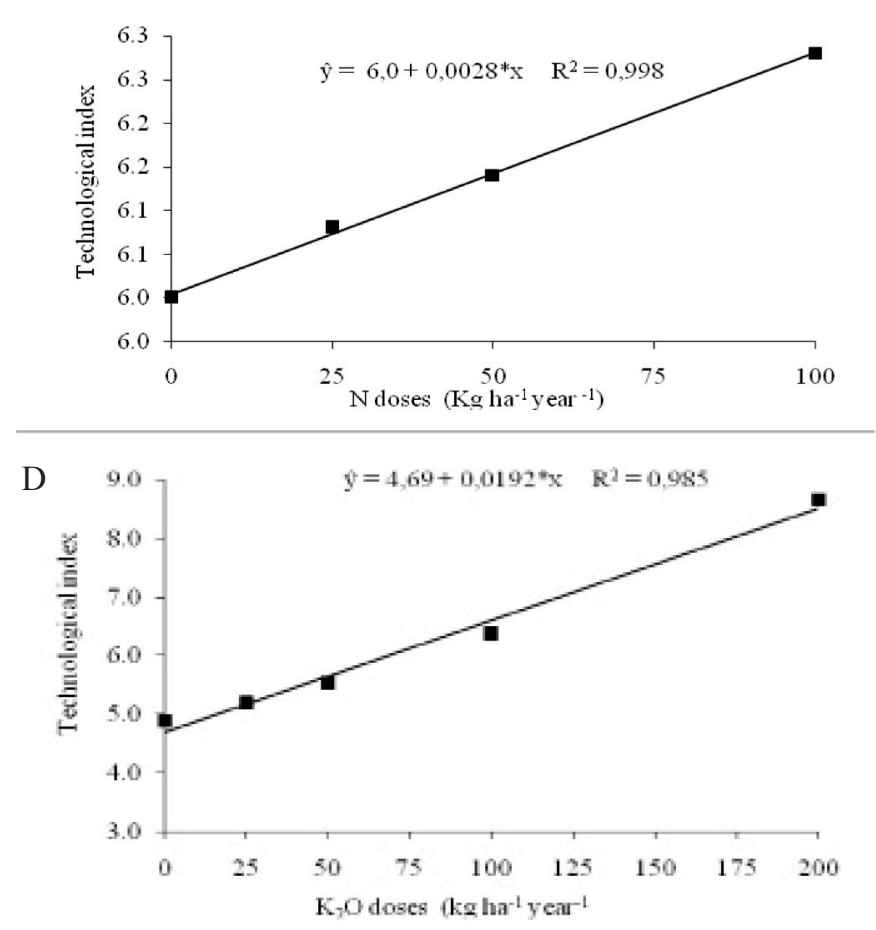

FIGURE 3 - Juice percentage (A and B) and technological index (C and D) of 'Tahiti' acid lime as a function of nitrogen and potassium doses applied to the soil.

$*=$ Significant at $5 \%$ probability. 


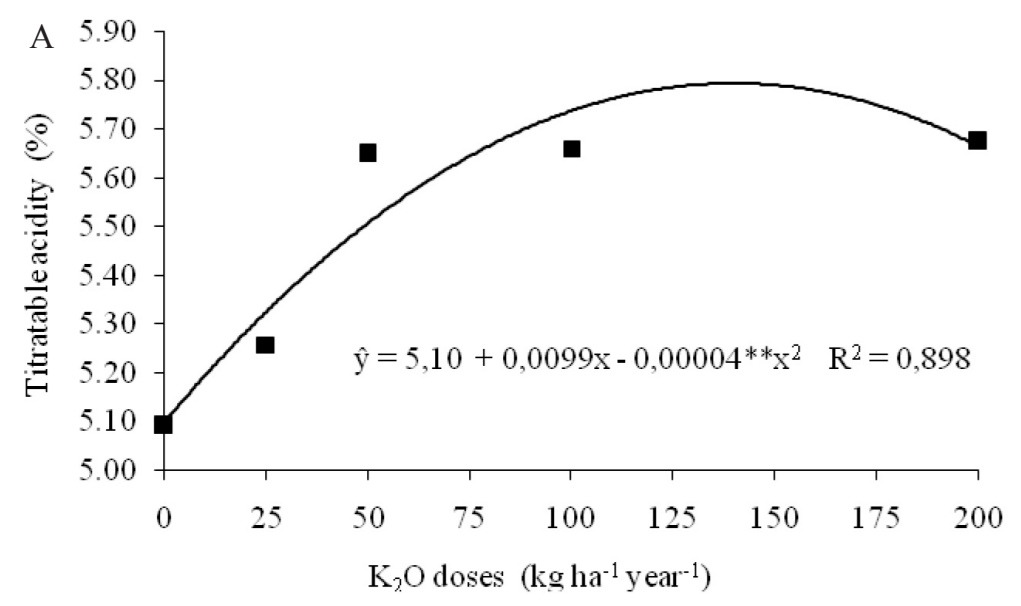

B

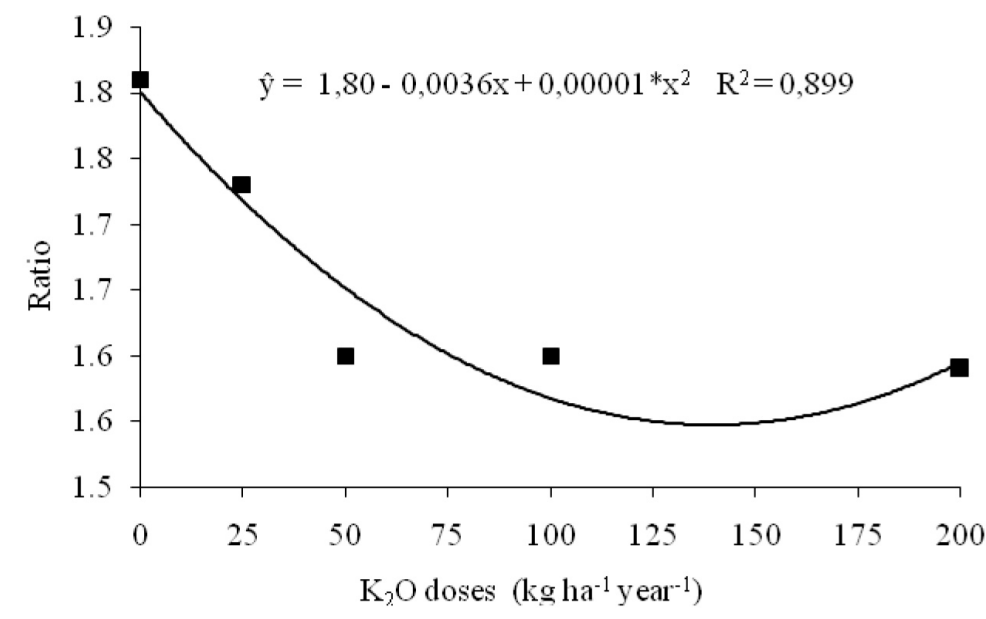

$\mathrm{C}$

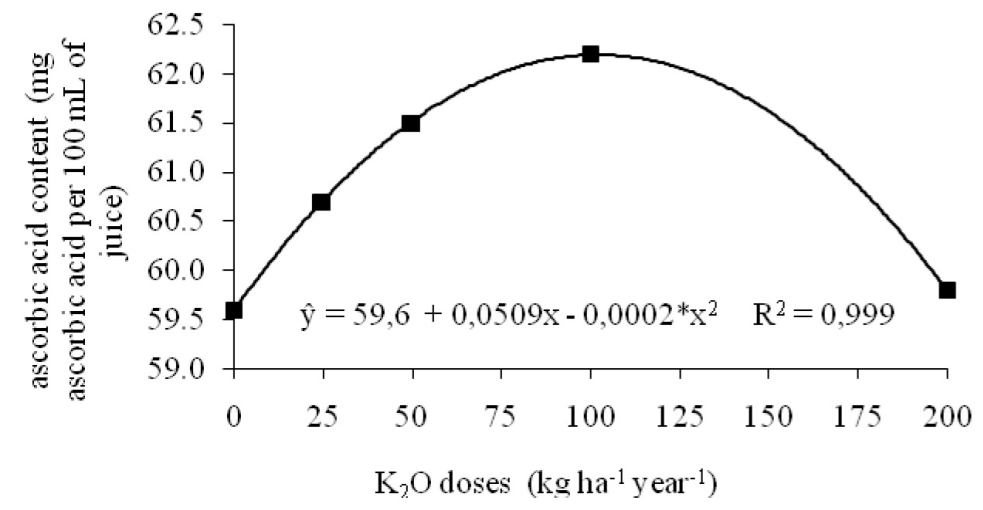

FIGURE 4-Titratable acidity (A), ratio (B) and ascorbic acid content (C) of 'Tahiti' acid lime as a function of potassium doses applied to the soil.

$*=$ Significant at $5 \%$ probability. 


\section{CONCLUSIONS}

Size, skin color, soluble solids content and $\mathrm{pH}$ of 'Tahiti' acid lime juice were not influenced by $\mathrm{N}$ and $\mathrm{K}_{2} \mathrm{O}$ fertilizations.

Skin thickness, juice percentage and technological index increased with $\mathrm{N}$ and $\mathrm{K}_{2} \mathrm{O}$ applied to the soil.

Juice volume and fruit firmness reduced with applications of $\mathrm{K}_{2} \mathrm{O}$ doses.

Titratable acidity and ascorbic acid content increased with $\mathrm{K}_{2} \mathrm{O}$ doses.

\section{ACKNOWLEDGMENTS}

To Fapemig for the financing of the project and scholarship grants

\section{REFERENCES}

ALMEIDA, M.C. de.; BAUMGARTNER, J.G. Efeitos da adubação nitrogenada e potássica na produção e na qualidade de frutos de laranjeira-'Valência'. Revista Brasileira de Fruticultura, Jaboticabal, v.24, n.1, p.282-4, 2002.

ALVA, A.K.; MATTOS JUNIOR, D.; PARAMASIVAM, S.; PATIL, B.; DOU, H.; SAJWAN, K.S. Potassium management for optimizing citrus production and quality. International Journal of Fruit Science, Binghamton, v.6, n.1, p.3-43, 2006.

AOAC - Association of Official Analytical Chemists. Official methods of analysis of AOAC International. 16 ${ }^{\text {th }}$ ed. Gaithersburg, 1995.

AULAR, J.; NATALE, W. Nutrição mineral e qualidade do fruto de algumas frutíferas tropicais: goiabeira, mangueira, bananeira e mamoeiro. Revista Brasileira de Fruticultura, Jaboticabal, v.35, n.4, p.1214-31, 2013.

AZEVEDO, C.L.L.; SANTOS FILHO, H.P.; COSTA, A.C.F.da. Produção integrada viabiliza certificação de propriedades de Lima Ácida 'Tahiti' no Norte de Minas Gerais. Cruz das Almas: Embrapa, 2010. (Comunicado Técnico, 144)
BASSAN, M.M.; MOURÃO FILHO, F. de A.A.; ALVES, R.F.; BEZERRA, D.F.; COUTO, H.T.Z.; JACOMINO, A.P. Postharvest packing process of 'Tahiti' acid lime affects their quality and conservation. Ciencia Rural, Santa Maria, v.46, n.1, p.184-190, 2016. Disponível em: $<$ http://www.scielo.br/scielo.php?script=sci arttext\&pid=S0103-84782016000100184\&lng=pt $\underline{\text { \&nrm=iso }}>$ Acesso em: 03 fev. 2016.

BERNARDI, A.C. de C.; WERNECK, C.G.; HAIM, P.G.; BOTREL, N.; OIANO-NETO, J.; MONTE, M.B.de M.; VERRUMA-BERNARDI, M.R. Produção e qualidade de frutos de tomateiro cultivado em substrato com zeólita. Horticultura Brasileira, Brasília, DF, v.25, n.2, p.306-11, 2007.

CARVALHO, C.R.L.; MANTOVANI, D.M.B.; CARVALHO, P.R.N.; MORAES, R.M.M. Análises químicas de alimentos. Campinas: ITAL, 1990. (Manual Técnico).

GPACC - Grupo Paulista de Adubação e Calagem para Citros. Recomendação para adubação e calagem para citros no Estado de São Paulo. Cordeirópolis, 1994. 27p.

HUNSCHE, M.; BRACKMANN, A.; ERNANI, P.R. Efeito da adubação potássica na qualidade póscolheita de maçãs 'Fuji'. Pesquisa Agropecuária Brasileira, Brasília, DF, v.38, n.4, p.489-96, 2003.

IBGE - Instituto Brasileiro de Geografia e Estatística. Cultura perene: limão. 2012. Disponível em: $\leq$ http://www.sidra.ibge.gov.br/bda/tabela/listabl. asp? $c=1613 \& n=0 \& u=0 \& z=p \& o=22 \&>$. Acesso em: 02 set. 2015.

LUCHETTI, M.A.; MATTOS JR, D.; DE NEGRI, J.D.; FIGUEIREDO, J.O. Aspectos gerais e distribuição de cultivo. In: MATTOS JR, D.; DE NEGRI, J.D.; FIGUEIREDO, J.O. (Ed.). Lima ácida Tahiti 1. Campinas: Instituto Agronômico, 2003. p.1-12.

MAGAlHÃES, A.F.J. Nutrição mineral e adubação dos citros irrigados. Cruz das Almas: Embrapa Mandioca e Fruticultura Tropical, 2006. (Circular Técnica, 79).

MATTOS JUNIOR, D. de; BOARETTO, R.M.; ZAMBROSI, F.C.B.; QUAGGIO, J.A. Nutrição de plantas cítricas. Informe Agropecuário, Belo Horizonte, v.35, n.281, p.54-63, 2014. 
MATTOS JUNIOR, D. de; QUAGGIO, J.A.; CANTARELLA, H. Nitrogênio e potássio afetam a produção e a qualidade de laranjas. Informações Agronômicas, Piracicaba, v.110, p.1-2, 2005. Disponível em: $<$ http://www.ipni.net/publication/ iabrasil.nsf/0/FEB721EBA2ACF64983257AA100 6BBB78/\$FILE/Page1-2-110.pdf.> . Acesso em: 04 set. 2013.

MATTOS JUNIOR, D.; MILANEZE, T.F.; AZEVEDO, F.A.; QUAGGIO, J.A. Soil nutrient availability and its impact on fruit quality of Tahiti acid lime. Revista Brasileira de Fruticultura, Jaboticabal, v.32, n.1, 2010.

MENDONÇA, L.M.V.L.; CONCEIÇÃO, A. da.; PIEDADE, J.; CARVALHO, V.D. de.; THEODORO, V.C. de A. Caracterização da composição química e do rendimento dos resíduos industriais do limão Tahiti (Citrus latifolia Tanaka). Ciência e Tecnologia de Alimentos, Campinas, v.26, n.4, p.870-4, 2006.

NASCIMENTO, L.M. do; SANTOS, P.C. dos. Controle de doenças fúngicas e de danos por frio em pós-colheita de lima ácida Tahiti. Arquivos do Instituto Biológico, São Paulo, v.80, n.2, p.193205, 2013. Disponível em: <http://www.scielo.br/ scielo.php?script $=$ sci arttext\&pid $=\mathrm{S} 18081657201$ 3000200008\&lng=en\&nrm=iso $>$ Acesso em: $28 \mathrm{de}$ set. 2015.

PACHECO, C. de A.; SCHINOR, E.H.; AZEVEDO, F.A. de.; BASTIANEL, M.; CRISTOFANI-YALY, M. Caracterização de frutos do tangor TM x LP 290 para mercado de fruta fresca. Revista Brasileira de Fruticultura, Jaboticabal, v.36, n.4, p.805-12, 2014. Disponível em: < http://www.scielo.br/scielo. php?pid=S0100-29452014000400006\&script $=$ sci arttext >. Acesso em: 29 jan. 2016.
QUAGGIO, J.A.; MATTOS JUNIOR, D.; CANTARELLA, H. Fruit yield and quality os sweet oranges affected by nitrogen, phosphorus, and potassium fertilization in tropical soils. Fruits, Paris, v.61, n.5, p.293-302, 2006.

SAEG. Sistema para análises estatísticas e genéticas. Versão 9.1. Viçosa: Universidade Federal de Viçosa, 2007. 1 CD-ROM.

SILVA, J.T.A.da. Adubação do limão 'Tahiti' com nitrogênio e potássio. Belo Horizonte: Epamig, 2015. (Circular Técnica 209)

SOUZA, F. de; ARGENTA, L.C.; NAVA, G.; ERNANI, P.R.; AMARANTE, C.V.T. do. Qualidade de maçãs 'Fuji' influenciada pela adubação nitrogenada e potássica em dois tipos de solo. Revista Brasileira de Fruticultura, Jaboticabal, v.35, n.1, p.305-15, 2013.

TAVARES, S.; CASTRO, P.R. de C.E.; KLUGE, R.A.; JACOMINO, A.P. Conservação póscolheita em lima ácida "Tahiti" tratada com 1-metilciclopropeno. Revista Iberoamericana de Tecnologia Postcosecha, México, v.6, n.1, p.43-9, 2004.

VOLPE, C.A.; SCHÖFFEL, E.R.; BARBOSA, J.C. Influência da soma térmica e da chuva durante o desenvolvimento de laranjas -'Valência' e 'Natal' na relação entre sólidos solúveis e acidez e no índice tecnológico do suco. Revista Brasileira de Fruticultura, Jaboticabal, v.24, n.2, 436-41, 2002. 